\title{
Exploring Corporate Bankruptcy in Belgian Private Firms
}

\author{
Loredana Cultrera $^{1} \&$ Bauweraerts Jonathan ${ }^{1}$ \\ ${ }^{1}$ Warocqué School of Business and Economics, University of Mons, Belgium \\ Correspondence: Loredana Cultrera, Warocqué School of Business and Economics, University of Mons, Place \\ Warocqué 17 - 7000 Mons, Belgium. Tel: 32-6537-3237. E-mail: Loredana.cultrera@umons.ac.be
}

Received: December 8, 2016

Accepted: January 9, 2017

Online Published: February 15, 2017

doi:10.5539/ijef.v9n3p108

URL: http://dx.doi.org/10.5539/ijef.v9n3p108

\begin{abstract}
The main purpose of this paper is to identify the financial antecedents of corporate bankruptcy by employing a robust variable selection procedure. Based on a sample of 1,338 Belgian private firms, a backward stepwise logistic regression technique is employed. The findings indicate that the likelihood of corporate bankruptcy is higher at lower levels of solvency, liquidity and profitability. Furthermore, our results reveal that corporate bankruptcy is more likely in older and larger firms.
\end{abstract}

Keywords: corporate bankruptcy, variable selection, financial distress, private firms

\section{Introduction}

Nowadays, a large debate surrounds the problematic of corporate bankruptcy due to the social and financial consequences such a critical event implies for various economic actors (Graham, Kim, Li, \& Qiu, 2014). Most scholars focusing on bankruptcy prediction aim to determine one or several variable(s) that explain corporate bankruptcy (Altman, 1968; Beaver, 1966; Ohlson, 1980). As a result, many studies try to identify potential predictors of corporate bankruptcy in order to obtain a more fine-grained understanding of this phenomenon (Tian, Yu, \& Guo, 2015). More specifically, a large amount of research has identified a variety of financial variables as relevant predictors of corporate bankruptcy (Altman, 1968; Beaver, 1966; Grice \& Ingram, 2001; Sandin \& Porporato, 2008; Wang, Ma, \& Yang, 2014).

Even if these models increase our knowledge of corporate bankruptcy, additional insights could be gained by considering more robust statistical methods to identify the most relevant and reliable bankruptcy predictors (Du Jardin, 2009). Indeed, despite the existence of numerous advanced selection techniques to detect corporate bankruptcy predictors in an efficient way (Tian et al., 2015), only few studies have adopted such methods to identify the antecedents of corporate bankruptcy (Wang et al., 2014). This study tries to bring fresh insights into this topic by proposing a backward stepwise logistic regression that highlights the role of accounting-based predictors in predicting corporate bankruptcy.

With consistent findings from a sample of 1,338 Belgian private firms, this study offers several contributions to the literature. First, it addresses a recent call for more robustness in the empirical analysis of corporate bankruptcy predictors (Kim, Jo, \& Shin, 2016). Indeed, prior research mainly tested the predictive nature of several accounting and market-based variables without employing elaborated selection techniques to identify relevant corporate bankruptcy predictors (Du Jardin, 2009). Second, this study offers additional evidence on the application of bankruptcy theories by applying a robust selection procedure to a large variety of potential predictors previously identified in the literature (Tian et al., 2015). Specifically, it shows that the use of elaborated selection procedures confirms the relevance of classical accounting-based variables as corporate bankruptcy predictors.

This article is articulated in different sections. First, we review the literature on the financial antecedents of corporate bankruptcy as well as the methods used to identify corporate bankruptcy predictors. Subsequently, the methodology and the results are reported. Finally, the results are discussed and several limitations and avenues for future research are identified in the concluding section.

\section{Literature Review}

Over the last five decades, predicting corporate bankruptcy has become a major topic in the finance literature (Sensini, 2015). Indeed, Beaver (1967) was the first to identify corporate bankruptcy predictors by employing a 
discriminant analysis on a single ratio. A few years later, Altman (1968) went further in the analysis and created a specific indicator of bankruptcy that is the Z-score, which aggregates five accounting ratios to obtain a more accurate picture of the antecedents of corporate bankruptcy. Over time, a large variety of more elaborated statistical methods have been used to identify new corporate bankruptcy predictors and improve the robustness of the models tested. As mentioned by Du Jardin (2009), methods such as probit regressions, discriminant analyses, neural networks and hazard models have significantly contributed to a better understanding of the phenomenon of corporate bankruptcy. While some of these procedures improve the robustness of the model, others are more specifically related to the selection of appropriate corporate bankruptcy predictors. As much research neglects connecting these two methods together, this study tries to offer novel insights on this topic by developing a backward stepwise logistic regression procedure that combines the robustness of the logit regression with a widely used variable selection process.

This study draws on logit regressions for several reasons. First, the main assumption of linear models is that the predictors are normally distributed and that the dependent variable is continuous, which often compromises the identification of corporate bankruptcy predictors given the categorical nature of corporate bankruptcy (the firm is bankrupt or not). Accordingly, logit regressions may be particularly useful as it allows researchers to select potential predictors that are not necessarily normally distributed to explain a categorical variable, that is corporate bankruptcy (Acosta-González \& Fernández-Rodríguez, 2014). Furthermore, this method has been found reliable in various studies (Du Jardin, 2009). Based on these arguments, this study draws on logistic regressions to determine corporate bankruptcy predictors in a robust way.

A second point that must be underlined is the selection technique used in this study. Previous works identified a vast amount of selection techniques that allows researchers to determine accurate and reliable corporate bankruptcy predictors. In a first step, most scholars gather a set of potential predictors whose predictive power has been shown in previous literature (Balcaen \& Ooghe, 2006). It means that a large part of existing studies only draws on prior works and neglect to proactively seek additional antecedents of corporate bankruptcy. Such a method could be problematic as it does not include ad hoc variables that account for the context-specific nature of corporate bankruptcy predictors (Sensini, 2015). To overcome this limitation, this study proposes to select potential predictors whose predictive power was demonstrated in the literature and to add ad hoc variables that could offer more accuracy on the predictive power of overlooked potential corporate bankruptcy predictors.

In a second step, scholars employ an automatic procedure that often relates to complete methods and heuristic methods (Tsai, 2009). Heuristic methods are often preferred over complete methods as it allows researchers to consider the selection criteria as non-monotonic. It means that heuristic methods explore all potential combinations for the selection criteria before focusing on a limited number of potential corporate bankruptcy predictors (Kim et al., 2016). Forward and backward stepwise procedures represent the most commonly employed selection procedures in the literature (Wang et al., 2014). These techniques allow researchers to include or exclude variables based on a variety of statistical criteria such as t-ratio statistics or the probability of F. However, few studies investigate the antecedents of corporate bankruptcy with the help of such methods, even if they improve the robustness of the findings (Du Jardin, 2009). Given the advantages of stepwise procedures, this study adopts a backward stepwise procedure to establish a robust and reliable model of corporate bankruptcy prediction.

In summary, this study draws on prior limitations observed in the literature to build a model of corporate bankruptcy prediction. More specifically, it tries to put together the use of logit regressions with a backward stepwise procedure to identify corporate bankruptcy predictors in a robust, reliable, and accurate way.

\section{Method}

\subsection{Data}

A sample of 1,338 unlisted bankrupt and non-bankrupt Belgian SMEs was developed with the Belfirst software, which is published annually by the Bureau van Dijk. The objective was to focus on SMEs, as such only firms employing fewer than 100 people were selected.

The bankrupt companies were selected on the basis of the previous year's annual accounts. In the case of this study, the last year was 2013. Only companies that filed accounts between 2010 and 2013 were selected. The final sample included 668 bankrupt SMEs.

To ensure the integration of healthy SMEs in the sample the applied logic was the same. However, here, the last year of filed accounts was chosen as 2014, to avoid the possibility of the 2013 filings coming from firms which went on to fail in 2013 or 2014. The aggregate sample included 3,970 healthy SMEs among which 668 SMEs 
were randomly selected to obtain a balanced final sample.

\subsection{Regression Procedure}

To take into account categorical nature of the dependent variable, a binary logit regression model was employed to build the model of corporate bankruptcy prediction. Such a method is frequently used in the literature to understand the antecedents of corporate bankruptcy (Johnsen \& Melicher, 1996; Tinoco \& Wilson, 2013). Basically, a binary logit regression model measures the relationship between the categorical dependent variable and one or more independent variables by estimating probabilities using a logistic function, which is the cumulative logistic distribution. Given the dichotomous nature of the dependent variable (the firm is bankrupt or not), it is characterized by the Bernoulli distribution such that $\mathrm{Pi}=\mathrm{P}(\mathrm{yi}=1)$ is the likelihood of corporate bankruptcy and $1-\mathrm{Pi}$ is the likelihood of corporate health.

The statistical model implies that the dependent variable represents a linear combinations of various exogenous variables and is presented as follows:

$$
y_{i}^{*}=\beta X_{i}+\varepsilon_{i} \text { where } \varepsilon \text { is the error term and } \beta \text { the vector of coefficients }
$$

and where

$$
\begin{aligned}
& y i=1 \text { if } \mathrm{yi}^{*}>0 \\
& \mathrm{yi}=0 \text { if } \mathrm{yi}^{*} \leq 0
\end{aligned}
$$

The likelihood of non-default (a posteriori) of business $i$ is given by:

$$
P(y i=0)=P\left(y i^{*} \leq 0\right)=P(\beta X i+\varepsilon i \leq 0)=P(\varepsilon i \leq-\beta X i)=F(-\beta X i)=1-F(\beta X i)=1-P i
$$

The likelihood of failure (a posteriori) of business $i$ is represented by:

$$
P(y i=1)=P\left(y i^{*}>0\right)=P(\beta X i+\varepsilon i>0)=P(\varepsilon i>-\beta X i)=1-P(\varepsilon i \leq-\beta X i)=F(\beta X i)=P i
$$

The logit model assumes that the errors follow a logistic distribution where the distribution function is:

$$
F(x)=(1+e-x)-1
$$

Therefore, it is possible to calculate the likelihood of being healthy for company $\mathrm{i}$ :

$$
P(y i=0)=F(-\beta X i)=(1+e \beta X i)-1=1-P i
$$

Similarly, the likelihood of corporate bankruptcy of a specific company $i$ is:

$$
P(y i=1)=F(X i \beta)=(1+e-\beta X i)-1=P i
$$

The method of maximum likelihood was used to determine the $\beta$ coefficients.

\subsection{Variable Selection}

\subsubsection{Dependent Variable}

Corporate Bankruptcy is a dummy variable that equals 1 if the firm has experienced corporate bankruptcy, 0 otherwise.

\subsubsection{Independent Variables}

Prior empirical works have employed a variety of financial indicators to identify corporate bankruptcy predictors (e.g. Agarwal \& Taffler, 2008; Altman, 2000; Altman \& Branch, 2015; Amendola, Restaino, \& Sensini, 2011; Dimitras, Zanakis, \& Zopoudinis, 1996; Jackson \& Wood, 2013; Kim et al., 2016; Sensini, 2015, 2016; Wang et al., 2014). While most studies did not use a robust variable selection technique to identify the most relevant corporate bankruptcy predictors (Du Jardin, 2009), the backward stepwise procedure used in this study helps overcome this critical issue (Kim \& Gu, 2006). Backward stepwise selection consists in starting with all potential predictors, testing the deletion of each potential predictor using a chosen model fit criterion, deleting the potential predictor (if any) whose loss gives the most statistically insignificant alteration of the model fit, and repeating this process until no further potential predictors can be deleted without a statistically significant loss of fit. Referring to prior works in the literature, this study includes 30 financial predictors that are commonly used and selected in predicting corporate bankruptcy (Agarwal \& Taffler, 2008; Altman, 1968; Altman \& Branch, 2015; Amendola, Restaino, \& Sensini, 2011; Balcaen \& Ooghe, 2006; Beaver, 1966; Dimitras, Zanakis, \&Zopoudinis, 1996; Jackson \& Wood, 2013; Kim et al., 2016; Ohlson, 1980; Wang et al., 2014). These indicators are reported in Table 1.

Several criteria were used to select the predictors during the stepwise backward selection. This study uses .05 as a $F$-to-remove statistic in order to exclude the least significant variable from the model at each step. Accordingly, 
one variable was dropped from the model if the $F$-to-remove statistic than .05 . Applying this stepwise backward procedure to the 30 potential corporate bankruptcy predictors reported in Table 1,5 predictors were finally included in the model:

Firm age is the age of the business without log-transformation. Firm size corresponds to the logarithmized measure of total employees. EBIT/TA is a profitability measure and is calculated as earning before interests and taxes divided by total assets. Solvency is a solvency indicator corresponding to (Net income + depreciation) divided by (Short-term liabilities + Long term liabilities). A measure of labor productivity, that is the value added per worker, is labelled $V A / T W$.

Table 1. List of potential corporate bankruptcy predictors

\begin{tabular}{llll}
\hline Variable & Abbreviation & Variable & Abbreviation \\
\hline Firm age & Firm age & Net income/Total assets & NI/TA \\
Log of total employees & Firm size & Cash-flow/Equity & CF/E \\
Shareholder equity/Total assets & Solvency & Cash-flow/Total liabilities & CF/TD \\
EBIT/Total assets & EBIT/TA & Net Working Capital/Sales & NWC/S \\
Current ratio & Current & Net Working Capital/Total assets & NWC/TA \\
Accruals/Total assets & Accruals & Long term liabilities/Equity & LTdebt/E \\
Value added/Total workers & VA/TW & Total liabilities/Total assets & TD/TA \\
Acid test & Acid & Cash-flow/Total liabilities & CF/TL \\
Log of sales & LnS & Net income/Current liabilities & NI/CL \\
Number of days of client credit & ClientDays & EBITDA/Total liabilities & EBITDA/TL \\
Number of days of supplier credit & SupplierDays & Cash-flow/Current assets & CF/CA \\
Long term liabilities/Total assets & LTL/TA & Net income/Total liabilities & NI/TL \\
Gross sales margin & GSM & Net income/Current assets & NI/CA \\
Net sales margin & NSM & Current liabilities/Sales & CL/S \\
Net income/Sales & NI/S & & \\
Tax expense/Total assets & Tax/TA & & \\
\hline
\end{tabular}

\section{Results}

\subsection{Descriptive Statistics}

Descriptives and correlations are presented in Table 2. Firm age and size are negatively correlated with corporate bankruptcy $(p<.01)$. A negative correlation is reported between corporate bankruptcy and the solvency ratio $(p$ $<.01)$ as well as the current ratio $(p<.01)$. It must also be noted that profitability is negatively related to corporate bankruptcy as EBIT/TA $(p<.01)$ and $V A / T W(p<.01)$ have a negative correlation with corporate bankruptcy. Additionally, positive correlations are reported between firm size and a set of financial ratios: solvency ratio $(p<.01)$, current ratio $(p<.01)$, EBIT/TA $(p<.01)$ and VA/TW $(\mathrm{p}<.01)$.

Table 2. Descriptive statistics and Pearson's correlation matrix

\begin{tabular}{|c|c|c|c|c|c|c|c|c|c|}
\hline Variable & Mean & S.D. & 1 & 2 & 3 & 5 & 6 & 7 & 8 \\
\hline 1. Bankruptcy & 0.172 & 0.378 & 1 & & & & & & \\
\hline 2. Firm age & 16.554 & 11.148 & $\begin{array}{l}-0.076 \\
* * *\end{array}$ & 1 & & & & & \\
\hline 3. Firm size & 5.762 & 1.852 & $\begin{array}{l}-0.233 \\
* * *\end{array}$ & $\begin{array}{l}0.237 \\
* * *\end{array}$ & 1 & & & & \\
\hline 4. Current & 3.337 & 8.351 & $\begin{array}{l}-0.123 \\
* * *\end{array}$ & $\begin{array}{l}0.081 \\
* * *\end{array}$ & $\begin{array}{l}0.057 \\
* * *\end{array}$ & 1 & & & \\
\hline 5. EBIT/TA & -2.232 & 93.549 & $\begin{array}{l}-0.053 \\
* * *\end{array}$ & -0.000 & $\begin{array}{l}0.096 \\
* * *\end{array}$ & 0.010 & 1 & & \\
\hline 6. Solvency & 36.149 & 38.841 & $\begin{array}{l}-0.386 \\
* * *\end{array}$ & $\begin{array}{l}0.152 \\
* * *\end{array}$ & $\begin{array}{l}0.095 \\
* * *\end{array}$ & $\begin{array}{l}0.381 \\
* * *\end{array}$ & $\begin{array}{l}0.217 \\
* * *\end{array}$ & 1 & \\
\hline 7. VA/TW & 84.314 & 121.427 & $\begin{array}{l}-0.193 \\
* * *\end{array}$ & 0.027 & $\begin{array}{l}0.322 \\
* * *\end{array}$ & $\begin{array}{l}0.064 \\
* * *\end{array}$ & $\begin{array}{l}0.145 \\
* * *\end{array}$ & $\begin{array}{l}0.151 \\
* * *\end{array}$ & 1 \\
\hline
\end{tabular}




\subsection{Regression Analysis}

The results of the backward stepwise logistic regression procedure are presented in Table 3. Firm size $(\beta=-0.113$, $p<.01)$ and age $(\beta=-0.012, p<.01)$ are negative linked with corporate bankruptcy. It means that larger and younger firms are more likely to be bankrupt. It also appears that profitability reduces the likelihood of corporate bankruptcy as EBIT/TA $(\beta=-3.417, p<.01)$ and $V A / T W(\beta=-0.038, p<.01)$ are negatively associated with corporate bankruptcy. Negative relations are also reported between the current ratio $(\beta=-0.242, p<.01)$ as well as the solvency ratio $(\beta=-0.041, p<.01)$ and corporate bankruptcy. Accordingly, firms with lower levels of liquidity and solvency are more likely to encounter corporate bankruptcy concerns.

Table 3. Logit regression

\begin{tabular}{|c|c|c|}
\hline & \multicolumn{2}{|c|}{ Logit regression } \\
\hline & Coef. & Std. Dev. \\
\hline Current & $-0.242 * * *$ & $(0.131)$ \\
\hline EBIT/TA & $-3.417 * * *$ & $(0.684)$ \\
\hline Solvency & $-0.041 * * *$ & $(0.002)$ \\
\hline VA/TW & $-0.038 * * *$ & $(0.006)$ \\
\hline Firm size & $-0.113 * * *$ & $(0.028)$ \\
\hline Firm age & $-0.012 * * *$ & $(0.001)$ \\
\hline Intercept & $1.917 * * *$ & $(0.009)$ \\
\hline Observations & \multicolumn{2}{|c|}{1338} \\
\hline Model Chi2 & \multicolumn{2}{|c|}{$439.76^{* * *}(6 \mathrm{df})$} \\
\hline Log Likelihood & \multicolumn{2}{|c|}{-382.476} \\
\hline
\end{tabular}

\section{Discussion}

Corporate bankruptcy remains one of the most widely explored topic in the literature at the intersection between accounting and finance. Despite the significant improvements brought to the understanding of this phenomenon over the last decades (Du Jardin, 2009), more research is needed to improve the accuracy and the robustness of corporate bankruptcy prediction models (Tian et al., 2015). Using a sample of 1,338 Belgian private firms, this study applies a backward stepwise logit regression procedure on a set of 30 accounting-based variables derived from prior literature and intuitive reasoning to build a robust and accurate corporate bankruptcy prediction model.

The results of this research reveal that a model of 6 variables is appropriate to explain corporate bankruptcy in private firms. Indeed, firm age, firm size, Solvency, Current, EBIT/TA, VA/TW are negatively related to corporate bankruptcy. These findings are in line with previous studies that highlight the predictive power of firm demographics, profitability, solvency and liquidity in corporate bankruptcy model (Altman, 1968; Beaver, 1966; Grice \& Ingram, 2001; Sandin \& Porporato, 2008; Wang et al., 2014). Interestingly enough, it must also be noted that ad hoc variables such as the proportion of tax expense or accruals in total assets did not exert any significant influence on corporate bankruptcy in private firms. An explanation for this could be that private firms are less inclined than large listed companies to use such earning management tools (Beatty, Ke, \& Petroni, 2002), thereby explaining the absence of significant relationships between the proposed ratios and corporate bankruptcy.

This research offers several contributions to the literature. First, the adoption of a backward stepwise logit regression procedure addresses a recent call for more empirical works using robust methods to select relevant and accurate corporate bankruptcy predictors (Wang et al., 2014). Additionally, the inclusion of ad hoc variables in the predictor selection process is also in line with recent advancements that underline the role of such variables in explaining corporate bankruptcy (Tian et al., 2015). Second, the results of this study tends to confirm that financial theories about corporate bankruptcy seems to hold in the context of private firms, an overlooked context so far (Du Jardin, 2009). Indeed, most empirical studies focus on large listed firms to analyze corporate bankruptcy while smaller private firms are often neglected even if they significantly contribute to the economic fabric (Memili et al., 2015).

Despite the noted contributions, this study is not free of limitations that must be mentioned to offer avenues for future research developments. First, this study draws on a backward stepwise logit regression procedure to 
predict corporate bankruptcy. Although this robust selection method is particularly appropriate to determine the antecedents of corporate bankruptcy (Du Jardin, 2009), more sophisticated procedures are emerging and could be used to confirm the findings. For instance, neural network analysis (Kim et al., 2016) or least absolute shrinkage and selection operator method (Tian et al., 2015) could be employed to strengthen the validity of this study. Second, the sample was limited to Belgian private firms. To ensure the external validity of this study and take into account cultural differences across countries (Lussier \& Halabi, 2010), it could be replicated in other national settings. It would also be interesting to reiterate the analysis with a sample of large publicly-traded firms to determine whether the ad hoc variables selected and found inaccurate in this research could represent good corporate bankruptcy predictors in that specific context. Third, this study only considers the role played by accounting-based indicators on corporate bankruptcy. Additional insights could be gained by introducing governance, behavioral and environmental variables or as potential corporate bankruptcy predictors.

Finally, we hope that, by improving our knowledge of corporate bankruptcy, this research will foster research efforts on this critical issue for academicians and practitioners.

\section{References}

Acosta-González, E., \& Fernández-Rodríguez, F. (2007). Model selection via genetic algorithms illustrated with $\begin{array}{lllll}\text { cross-country growth data. } & \text { Empirical }\end{array}$ http://dx.doi.org/10.1007/s00181-006-0104-3

Acosta-González, E., \& Fernández-Rodríguez, F. (2014). Forecasting financial failure of firms via genetic algorithms. Computational Economics, 43(2), 133-157. http://dx.doi.org/10.1007/s10614-013-9392-9

Agarwal, V., \& Taffler, R. (2008). Comparing the Performance of Market-based and Accounting based Bankruptcy Prediction Models. Journal of Banking and Finance, 32(8), 1541-1551. http://dx.doi.org/10.1016/j.jbankfin.2007.07.014

Altman, E. I. (1968). Financial ratios, discriminant analysis and the prediction of corporate bankruptcy. The Journal of Finance, 23(4), 589-609. http://dx.doi.org/10.2307/2978933

Altman, E. I. (2000). Predicting financial distress of companies: Revisiting the Z-score and ZTM model. New York University, Working Paper.

Altman, E. I., \& Branch, B. (2015). The Bankruptcy System's Chapter 22 Recidivism Problem: How Serious is It. The Financial Review, 50(1), 1-26. http://dx.doi.org/10.1111/fire.12058

Amendola, A., Restaino, M., \& Sensini, L. (2011). Variable Selection in Default Risk Models. The Journal of Risk Model Validation, 5(1), 3-19. http://dx.doi.org/10.21314/JRMV.2011.066

Balcaen, S., \& Ooghe, H. (2006). 35 years of studies on business failure: An overview of the classic statistical methodologies and their related problems. The British Accounting Review, 38(1), 63-93. http://dx.doi.org/10.1016/j.bar.2005.09.001

Beatty, A. L., Ke, B., \& Petroni, K. R. (2002). Earnings management to avoid earnings declines across publicly and privately held banks. The Accounting Review, 77(3), 547-570. https://doi.org/10.2308/accr.2002.77.3.547

Beaver, W.H. (1966). Financial ratios as predictors of failure. Journal of Accounting Research, 4, 71-111. http://dx.doi.org/10.2307/2490171

Dimitras, A. I., Zanakis, S. H., \& Zopoudinis, C. (1996). A survey of business failures with an emphasis on failure prediction methods and industrial applications. European Journal of Operational Research, 90(3), 487-513. http://dx.doi.org/10.1016/0377-2217(95)00070-4

Du Jardin, P. (2009). Bankruptcy prediction models: How to choose the most relevant variables? Bankers, Markets \& Investors, 98, 39-46.

Graham, J. R., Kim, N. H., Li, S., \& Qiu, J. (2014). The Labor Impact of Corporate Bankruptcy: Evidence from Worker-Firm Matched Data. Available at SSRN 2276753.

Grice, J. S., \& Ingram, R. W. (2001). Tests of the generalizability of Altman's bankruptcy prediction model. Journal of Business Research, 54(1), 53-61. https://doi.org/10.1016/S0148-2963(00)00126-0

Jackson, R. H. G., \& Wood, A. (2013). The Performance of Insolvency Prediction and Credit Risk Models in the U.K: A Comparative Study. The British Accounting Review, 45(3), 183-202. http://dx.doi.org/10.1016/j.bar.2013.06.009 
Johnsen, T., \& Melicher, R. W. (1994). Predicting corporate bankruptcy and financial distress: Information value added by multinomial logit models. Journal of Economics and Business, 46(4), 269-286. https://doi.org/10.1016/0148-6195(94)90038-8

Kim, H. J., Jo, N. O., \& Shin, K. S. (2016). Optimization of cluster-based evolutionary undersampling for the artificial neural networks in corporate bankruptcy prediction. Expert Systems with Applications, 59, 226-234. https://doi.org/10.1016/j.eswa.2016.04.027

Kim, H., \& Gu, Z. (2006). A logistic regression analysis for predicting bankruptcy in the hospitality industry. The $\begin{array}{llll}\text { Journal of Hospitality Financial Management, } & \text { 14(1), }\end{array}$ https://doi.org/10.1080/10913211.2006.10653812

Lussier, R. N., \& Halabi, C. E. (2010). A three-country comparison of the business success versus failure prediction model. Journal of Small Business Management, 48(3), 360-377. https://doi.org/10.1111/j.1540-627X.2010.00298.x

Memili, E., Fang, H., Chrisman, J. J., \& De Massis, A. (2015). The impact of small-and medium-sized family firms on economic growth. Small Business Economics, 45(4), 771-785. https://doi.org/10.1007/s11187-015-9670-0

Ohlson, J. A. (1980). Financial ratios and the probabilistic prediction of bankruptcy. Journal of Accounting Research, 18(1), 109-131. http://dx.doi.org/10.2307/2490395

Sandin, A. R., \& Porporato, M. (2008). Corporate bankruptcy prediction models applied to emerging economies: Evidence from Argentina in the years 1991-1998. International Journal of Commerce and Management, 17(4), 295-311. https://doi.org/10.1108/10569210710844372

Sensini L. (2016), An empirical analysis of Financially Distressed Italian companies. International Business Research, 9(10), 75-85. http://dx.doi.org/10.5539/ibr.v9n10p75

Sensini, L. (2015). Selection of determinants in Corporate Financial Distress. European Journal of Business and Management, 7(2), 73-82.

Shumway, T. (2001). Forecasting bankruptcy more accurately: A simple hazard model. The Journal of Business, 74(1), 101-124. http://dx.doi.org/10.2139/ssrn.171436

Tian, S., Yu, Y., \& Guo, H. (2015). Variable selection and corporate bankruptcy forecasts. Journal of Banking \& Finance, 52, 89-100. http://dx.doi.org/10.1016/j.jbankfin.2014.12.003

Tinoco, M. H., \& Wilson, N. (2013). Financial distress and bankruptcy prediction among listed companies using accounting, market and macroeconomic variables. International Review of Financial Analysis, 30, 394-419. http://dx.doi.org/10.1016/j.irfa.2013.02.013

Tsai, C. F. (2009). Feature selection in bankruptcy prediction. Knowledge-Based Systems, 22(2), 120-127. http://dx.doi.org/10.1016/j.knosys.2008.08.002

Wang, G., Ma, J., \& Yang, S. (2014). An improved boosting based on feature selection for corporate bankruptcy prediction. Expert Systems with Applications, 41(5), 2353-2361. https://doi.org/10.1016/j.eswa.2013.09.033

\section{Copyrights}

Copyright for this article is retained by the author(s), with first publication rights granted to the journal.

This is an open-access article distributed under the terms and conditions of the Creative Commons Attribution license (http://creativecommons.org/licenses/by/4.0/). 